\title{
CHARACTERIZATION OF SiC CRYSTALS BY OPTICAL AND ELECTRICAL MEANS
}

\author{
K. Neimontas, R. Vasiliauskas, A. Mekys, J. Storasta, and K. Jarašiūnas \\ Institute of Materials Science and Applied Research, Vilnius University, Sauletekio 9, LT-10222 Vilnius, Lithuania \\ E-mail: kestutis.jarasiunas@ff.vu.lt
}

Received 22 October 2007; revised 15 November 2007; accepted 21 November 2007

\begin{abstract}
Measurements of carrier transport have been carried out in different $\mathrm{SiC}$ polytypes by using two complementary techniques: a picosecond four-wave mixing and magnetoresistance. Both techniques confirmed the mechanism of phonon scattering in $T=$ 100-300 K range, as well as higher carrier mobility in $n$-type $4 \mathrm{H}$ epitaxial layers with respect to 3C-SiC. The optical technique revealed a decrease of the bipolar mobility in $3 \mathrm{C}-\mathrm{SiC}$ at $T<100 \mathrm{~K}$ and its variation with photoexcited carrier density. A lattice heating was observed in free standing $3 \mathrm{C}$ - and $4 \mathrm{H}-\mathrm{SiC}$ due to strong impact of nonradiative recombination, and this effect precluded optical studies of carrier dynamics at low temperatures.
\end{abstract}

Keywords: silicon carbide, carrier transport, lattice heating, transient gratings

PACS: 72.20.Jv, 78.47.+p

\section{Introduction}

Devices made from $\mathrm{SiC}$ have been under extensive development in the past two decades and some of them are already commercialized. They often operate at high carrier densities, therefore it is important to determine carrier plasma parameters under adequate conditions. Non-destructive monitoring of carrier plasma parameters at high injection conditions is possible by using "excite-probe" optical techniques, which explore the light-induced changes of absorption or refractive index by free carriers $[1,2]$. Transient grating, or four-wave mixing technique (FWM) may provide all-optical evaluation of carrier transport and recombination processes in a wide range of excitations. Moreover, optical carrier injection at different wavelengths with quantum energies above the bandgap makes it possible to vary indepth resolution, to reach high nonequilibrium carrier density, and to study carrier density dependent photoelectric processes [3].

In this work, we applied the optical and electrical techniques to study carrier dynamics and transport in differently grown $4 \mathrm{H}-\mathrm{SiC}$ and $3 \mathrm{C}-\mathrm{SiC}$ samples in 10 $300 \mathrm{~K}$ range. By optical technique, we determined the temperature dependence of the bipolar carrier mobility in wide range of excitations. Comparative electrical measurements in 100-300 K range confirmed the dominant phonon scattering mechanism in the given tem- perature range. At lower temperatures $(T<100 \mathrm{~K})$, a decrease of bipolar mobility in $3 \mathrm{C}-\mathrm{SiC}$ reflected the ionized impurity scattering, while the screening of local charge by higher nonequilibrium carrier density resulted in higher mobility values. Moreover, at temperatures below $100 \mathrm{~K}$, we observed strong contribution of a lattice heating to refractive index modulation, and this effect precluded optical studies of carrier dynamics at temperatures below $100 \mathrm{~K}$ in the samples with high defect density.

\section{Samples}

We performed measurements of nonequilibrium carrier dynamics in $n$-type 3C-SiC (111) epilayer grown by vapour-liquid-solid (VLS) mechanism on $6 \mathrm{H}-\mathrm{SiC}$ (0001) and carried out comparative studies on freestanding bulk 3C-SiC (001) material originally grown on Si by HOYA Co. The $5 \mu$ m thick $n$-type $\left(n_{0} \approx\right.$ $10^{17} \mathrm{~cm}^{-3}$ ) 3C-SiC (111) epilayer was elaborated in two steps: firstly, a $2 \mu \mathrm{m}$ double-positioning boundary (DBP) free layer was grown by VLS mechanism in Ge-Si melt as described in Ref. [4]. After wet etching of the sample in acid solution to remove the remaining Ge-Si alloy on the surface, the 3C-SiC layer was thickened to $5 \mu \mathrm{m}$ by standard chemical vapour deposition (CVD) growth at $1450{ }^{\circ} \mathrm{C}$ using a mixture of silane and propane diluted in $\mathrm{H}_{2}$. 


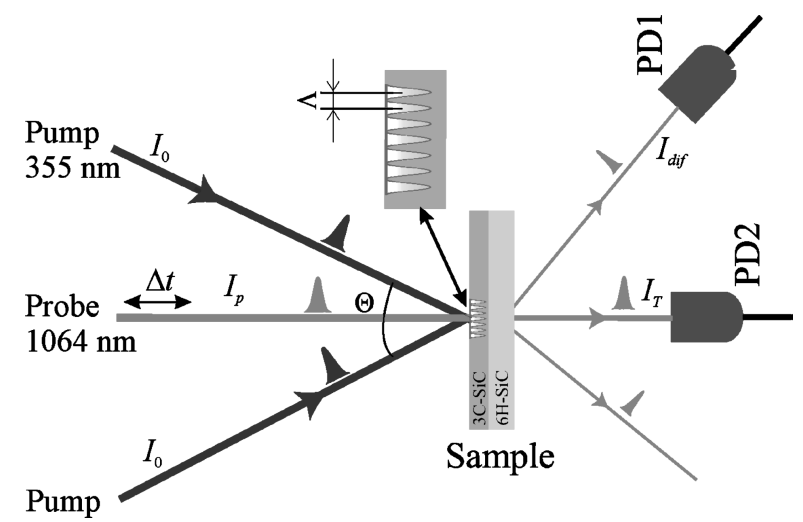

Fig. 1. Optical configuration for a surface grating recording. $I_{0}$, $I_{\mathrm{p}}, I_{\mathrm{dif}}$, and $I_{\mathrm{T}}$ are the intensities of pump, probe, diffracted, and transmitted beams, correspondingly, $\Lambda$ is the period of diffraction pattern, $\Theta$ is the angle between pump beams.

The measurements were also performed on two differently grown $n$-type $4 \mathrm{H}-\mathrm{SiC}$ epilayers. One of them was $35 \mu \mathrm{m}$ thick layer $\left(n_{0}=10^{16} \mathrm{~cm}^{-3}\right)$ grown by CVD on a heavily doped $\left(n_{0}=10^{19} \mathrm{~cm}^{-3}\right) 4 \mathrm{H}-\mathrm{SiC}$ substrate. The second one was $30 \mu \mathrm{m}$ thick layer $\left(n_{0}=\right.$ $5 \cdot 10^{15} \mathrm{~cm}^{-3}$ ) grown by sublimation technique on a semi-insulating $4 \mathrm{H}-\mathrm{SiC}$ substrate.

\section{Experimental technique}

The samples were excited by the interference pattern of two 25 ps duration laser beams at $355 \mathrm{~nm}$ wavelength, which created a periodically modulated nonequilibrium carrier density $N(x)=N_{0}+\Delta N$ $\times \cos (2 \pi x / \Lambda)$ with the period $\Lambda$ and refractive index modulation by free carriers $\Delta n_{\mathrm{FC}}(x, t) \sim \Delta N(x, t)$ [2]. The incident light was absorbed in a layer of thickness $d=\alpha^{-1} \sim 48 \mu \mathrm{m}$ (in 4H-SiC) or $d \sim 4.5 \mu \mathrm{m}$ (in 3C-SiC sample), in accordance with the absorption coefficient $\alpha$, thus creating the nonequilibrium ambipolar carrier plasma of density up to $10^{18} \mathrm{~cm}^{-3}$. A delayed probe pulse at $1064 \mathrm{~nm}$, to which $\mathrm{SiC}$ samples were transparent, monitored the instantaneous diffraction efficiency (Fig. 1) of the grating $\eta=I_{\text {dif }} / I_{\mathrm{T}}$ (here $I_{\text {dif }}$ is the diffracted and $I_{\mathrm{T}}$ is the transmitted probe beam intensity), which is proportional to the square of refractive index modulation, i.e. $\eta(t) \sim \Delta n_{\mathrm{FC}}^{2}(t)=\left(n_{\mathrm{eh}} \Delta N\right)^{2}$ ( $n_{\mathrm{eh}}$ is refractive index change induced by one electronhole pair) [2]. The carrier grating decay time $\tau_{\mathrm{G}}$ is obtained by an exponential fit of diffraction efficiency decay kinetics $\eta \sim \exp \left(-2 t / \tau_{\mathrm{G}}\right)$. The grating is erased by carrier recombination and lateral diffusion processes, therefore $\tau_{\mathrm{G}}$ can be expressed through ambipolar diffu- sion coefficient $D_{\mathrm{a}}$ and carrier recombination time $\tau_{\mathrm{R}}$ [2]:

$$
\frac{1}{\tau_{\mathrm{G}}}=\frac{1}{\tau_{\mathrm{R}}}+\frac{4 \pi^{2} D_{\mathrm{a}}}{\Lambda^{2}} .
$$

The decay of free-carrier grating with carrier density $N(x, t)$ is described by

$$
\begin{aligned}
\frac{\partial N(x, t)}{\partial t}= & D_{\mathrm{a}}(N) \frac{\partial^{2} N(x, t)}{\partial x^{2}}-\frac{N(x, t)}{\tau_{\mathrm{R}}} \\
& -B N^{2}(x, t)-C N^{3}(x, t)+G(x, t) .
\end{aligned}
$$

Here $C$ is the Auger recombination coefficient, $B$ is the bimolecular recombination coefficient, and $G(x, t)=$ $\alpha I(x, t) /(h \nu)$ is the carrier generation function.

For the measurements of magnetoresistance, the samples were made as classic Hall bar-shape pieces $\left(2 \times 5 \times 0.4 \mathrm{~mm}^{3}\right)$ with planar indium contacts. Samples were placed in a nitrogen-cooled cryostat with magnetic field $B=1.75 \mathrm{~T}$. Current was controlled with a KEITHLEY 6430 multimeter. The measurements were performed in 100-400 K temperature range.

From magnetoresistivity measurements, the magnetoresistant mobility of equilibrium carriers can be calculated [5]:

$$
\mu_{\mathrm{M}}=\frac{r_{\mathrm{M}}}{B} \sqrt{\frac{\rho_{B}-\rho_{0}}{\rho_{0}}},
$$

here $B$ is applied magnetic field, $\rho_{B}$ is magnetoresistivity, $\rho_{0}$ is resistivity, $r_{\mathrm{M}}$ is a constant which depends on sample geometry and scattering mechanisms. The magnetoresistant mobility is mainly influenced by the largest current. Therefore, for $n$-type samples with mobility of electrons being higher than that of holes $\left(\mu_{\mathrm{h}} \ll \mu_{\mathrm{n}}\right)$, the magnetoresistant mobility reflects the electron mobility. Carrier scattering mechanisms can be identified from the index value of the temperature dependence of magnetoresistant mobility: if phonon scattering dominates, then $\mu_{\mathrm{M}} \sim T^{-3 / 2}$, if ionized impurities $-\mu_{\mathrm{M}} \sim T^{3 / 2}$, if dislocations $-\mu_{\mathrm{M}} \sim T$ [6].

\section{Results and discussion}

We measured grating decay kinetics at different grating periods $\Lambda$ (in range from 2.7 to $14 \mu \mathrm{m}$ ), excitation intensities, and temperatures $(10-300 \mathrm{~K})$. Using a set of the measured grating kinetics at various periods and the corresponding grating decay times $\tau_{\mathrm{G}}$, we determined the bipolar diffusion coefficients $D_{\mathrm{a}}$ and carrier lifetimes by using Eq. (1). The bipolar mobility values $\mu_{\mathrm{a}}$ were obtained from the Einstein relation 

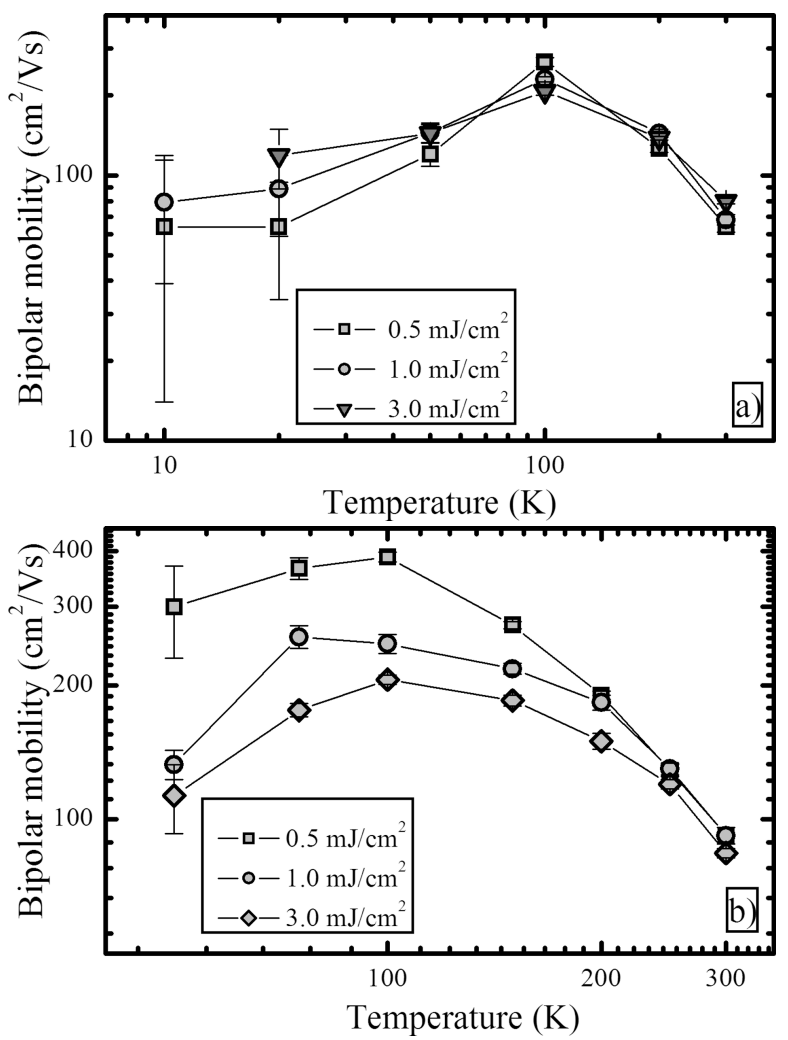

Fig. 2. Temperature dependence of a bipolar mobility in (a) $3 \mathrm{C}-\mathrm{SiC}$ (111) epitaxial layer and (b) free standing 3C-SiC (001) substrate at different excitation energy densities.

$D_{\mathrm{a}}=(k T / e) \mu_{\mathrm{a}}$. Under our experimental conditions, the electron and hole concentrations are equal $\left(\Delta N_{\mathrm{e}} \approx\right.$ $\left.\Delta N_{\mathrm{h}}\right)$, thus the hole mobility $\left(\mu_{\mathrm{h}} \ll \mu_{\mathrm{n}}\right)$ limits the value of bipolar diffusion coefficient $D_{\mathrm{a}} \approx 2 D_{\mathrm{h}}=2 k T \mu_{\mathrm{h}} / e$. The hole mobility in free standing 3C-SiC layer at $300 \mathrm{~K}$ was found to be equal to $\mu_{\mathrm{h}}=(40 \pm 5) \mathrm{cm}^{2} /(\mathrm{V} \mathrm{s})$, and a slightly smaller value of $\mu_{\mathrm{h}}=(35 \pm 5) \mathrm{cm}^{2} /(\mathrm{V} \mathrm{s})$ was found in epitaxial DPB free layer. The decrease of bipolar mobility (see Fig. 2(a,b)) at low temperatures $(T<100 \mathrm{~K})$ reflected the ionized impurity scattering, while at higher temperatures $(T>100 \mathrm{~K})$ the phonon scattering dominated. In the conditions of ionized impurity scattering, we found a tendency of mobility increase with increasing excitation density for the epitaxial 3C-SiC layer, while in the free standing 3C-SiC layer the effect was opposite: the $\mu$ value decreased from 300 to $110 \mathrm{~cm}^{2} /(\mathrm{V} \mathrm{s})$ at $T=50 \mathrm{~K}$, see Fig. 2(b). These tendencies can be attributed to screening of the charge at contributing defect states by high carrier density. Carrier mobility values were found to be higher in the free standing layer in all measured temperature range, and that shows better electrical properties of the sample in comparison with the DPB free epilayer. In the latter sample, photoluminescence measurements revealed high density of shallow impurities (above $10^{18} \mathrm{~cm}^{-3}$ )

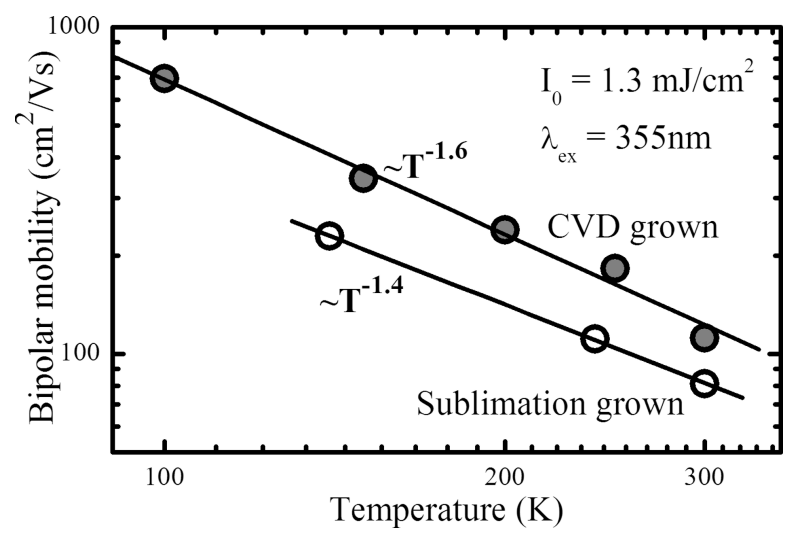

Fig. 3. Temperature dependence of bipolar carrier mobility in differently grown $n$-type $4 \mathrm{H}$-SiC epilayers.

[7], while in the bulk 3C-SiC the concentration of nitrogen donors was in mid- $10^{15} \mathrm{~cm}^{-3}$ [8].

In Fig. 3 we show the decrease of bipolar mobility with temperature at two different $4 \mathrm{H}-\mathrm{SiC}$ epilayers at $I_{0}=1.3 \mathrm{~mJ} / \mathrm{cm}^{2}$ excitation intensity. The measured temperature dependence $\mu_{\mathrm{a}} \sim T^{-A}$ was found to be similar to those typical for phonon (lattice) scattering mechanism [9] and provided the index value $A=$ 1.4 for sublimation grown epilayer and $A=1.6$ for CVD grown epilayer. The similar slope values $A$ were found in $n$ - and $p$-type $4 \mathrm{H}-\mathrm{SiC}$ samples in temperature range $100-300 \mathrm{~K}$ [10-12]. Our data provided $\mu_{\mathrm{h}}=$ $60 \mathrm{~cm}^{2} /(\mathrm{V} \mathrm{s})$ for the CVD grown sample and $\mu_{\mathrm{h}}=$ $40 \mathrm{~cm}^{2} /(\mathrm{V} \mathrm{s})$ for the sublimation grown one at room temperature, that was in good agreement with the Hall data in low doped $4 \mathrm{H}-\mathrm{SiC}$ epilayers, which provided the hole mobility in range of $60-120 \mathrm{~cm}^{2} /(\mathrm{V} \mathrm{s})[12,13]$. From Fig. 3 we see that the determined bipolar mobility (diffusion coefficient) values at the same experimental conditions are higher in the CVD grown sample. This can be attributed to the different concentrations of defects.

Carrier scattering mechanisms in $3 \mathrm{C}-\mathrm{SiC}$ were determined from the magnetoresistance measurements at different temperatures (see Fig. 4). The ionized impurities start to limit the carrier mobility at lower temperatures, but the effect is more pronounced in the epitaxial $3 \mathrm{C}-\mathrm{SiC}$ layer with respect to $4 \mathrm{H}-\mathrm{SiC}$ (see Fig. 4). The expected tendencies for scattering by phonons $\left(\mu_{\mathrm{M}} \sim\right.$ $\left.T^{-3 / 2}\right)$ or by ionized impurities $\left(\mu_{\mathrm{M}} \sim T^{3 / 2}\right)$ are shown in Fig. 4 by dotted lines [6]. We note that the observed scattering mechanisms of equilibrium carriers by magnetoresistance measurements in $100-300 \mathrm{~K}$ temperature interval correlate well with those measured by FWM for highly excited carriers (see Figs. 2, 3, and 4).

The measurements of grating kinetics in highly- 


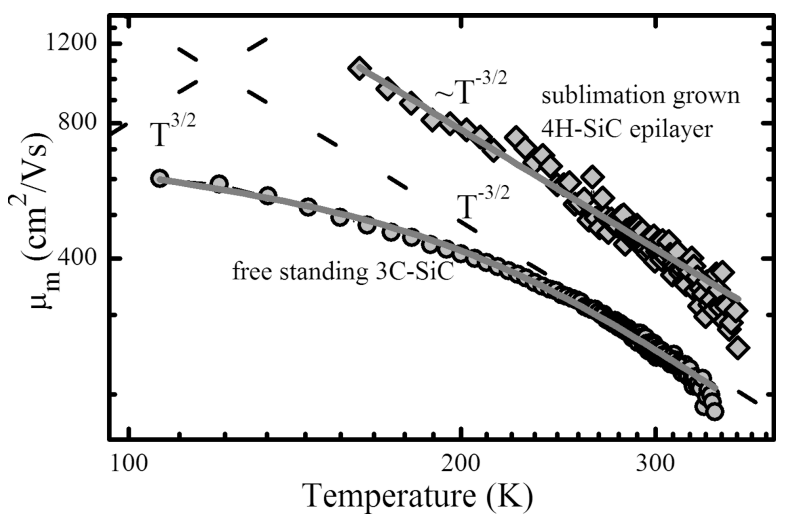

Fig. 4. Magnetoresistant mobility dependence on temperature in free standing $3 \mathrm{C}$-SiC substrate and in $n$-type $4 \mathrm{H}-\mathrm{SiC}$ epilayer grown by sublimation technique.

excited free standing 3C-SiC sample at temperatures $T<50 \mathrm{~K}$ revealed the effect which had been earlier observed in $4 \mathrm{H}-\mathrm{SiC}$ crystals [14]. The diffraction efficiency kinetics at low temperatures pointed out the contribution of lattice heating to refractive index modulation (see Fig. 5). This effect was earlier observed both in CVD grown $4 \mathrm{H}-\mathrm{SiC}$ epilayer at temperatures $T<100 \mathrm{~K}$ as well as in sublimation grown sample at $T<150 \mathrm{~K}$ [14]. This effect was mainly attributed to nonradiative carrier recombination and lattice heating due to excess quantum energy. In Fig. 5 the grating decay kinetics measured in free standing $3 \mathrm{C}$-SiC sample at different temperatures are presented. The grating decay is single exponential at $T=100 \mathrm{~K}$, while at lower temperatures the kinetics become non-exponential and reveal contribution of another mechanism of refractive index modulation. We attribute this effect to refractive index modulation by temperature, previously observed in $\mathrm{Si}$ and $4 \mathrm{H}-\mathrm{SiC}[14,15]$. We have found that the contribution of coexisting temperature grating in $3 \mathrm{C}-\mathrm{SiC}$ is increasing at lower temperature (Fig. 5) and higher excitation energies. At larger grating periods, the contribution of the thermal grating to the total diffraction efficiency is observed at later times (see Fig. 6) or even disappears at $\Lambda=15.9 \mu \mathrm{m}$, as the carrier grating modulation is less erased by diffusion and persists for a longer time. In the inset of Fig. 6 the kinetics of diffraction efficiency measured in DBP free epilayer at $T=$ $10 \mathrm{~K}$ and different grating periods are shown. As we see, the lattice heating effect is not present in the sample. Assuming that the lattice heating due to quantum excess energy, nonradiative Auger recombination, and free carrier absorption is similar for both 3C-SiC samples, the more pronounced lattice heating in free standing $3 \mathrm{C}$-SiC layers should be attributed to the additional channels of nonradiative recombination. More detailed analysis of the effect will require an elaborate numerical simulation of carrier dynamics and heating in subnanosecond time domain, using the determined temperature and carrier density dependent mobility and lifetime values in $3 \mathrm{C}-\mathrm{SiC}$ layers.

\section{Summary}

The measurements of carrier mobility have been carried out in $3 \mathrm{C}-\mathrm{SiC}$ and $4 \mathrm{H}-\mathrm{SiC}$ by using a picosecond four-wave mixing and magnetoresistance techniques. Both techniques confirmed the mechanism of phonon scattering in $T=100-300 \mathrm{~K}$ range in $4 \mathrm{H}-\mathrm{SiC}$. Higher carrier mobility was found in $4 \mathrm{H}-\mathrm{SiC}$ epitaxial layers grown by standard CVD with respect to $4 \mathrm{H}-\mathrm{SiC}$ layers grown by sublimation technique, and attributed to higher concentration of defects. Temperature dependences of carrier mobility in 3C-SiC samples confirmed phonon scattering ( $T=100-300 \mathrm{~K}$ ), while at lower temperatures $(T<100 \mathrm{~K})$ we found ionized impurity governed decrease of carrier mobility. A lattice heating was observed in free standing $3 \mathrm{C}-\mathrm{SiC}$ and $4 \mathrm{H}-\mathrm{SiC}$ due to strong impact of nonradiative recombination, and this effect precluded optical studies of carrier dynamics at $T<50 \mathrm{~K}$ in $3 \mathrm{C}-\mathrm{SiC}$ and at $T<100 \mathrm{~K}$ in $4 \mathrm{H}-\mathrm{SiC}$.

\section{Acknowledgements}

The research was supported by the Lithuanian State Science and Studies Foundation. R. Vasiliauskas acknowledges R. Yakimova, M. Syvajarvi, and G. Ferro for providing samples for the electrical measurements.

\section{References}

[1] P. Grivickas, J. Linnros, and V. Grivickas, Mater. Sci. Forum 338-342, 671-674 (2000).

[2] K. Jarašiūnas, in: UV Solid-State Light Emitters and Detectors, NATO Science Series II: Mathematics, Physics and Chemistry, Vol. 144, eds. M.S. Schur and A. Žukauskas (Kluwer Academic Publishers, 2004) pp. 93-109.

[3] K. Neimontas, R. Aleksiejūnas, M. Sūdžius, K. Jarašiūnas, and J.P. Bergman, Mater. Sci. Forum 483-486, 413-416 (2005).

[4] M. Soueidan and G. Ferro, Adv. Funct. Mater. 16, 975978 (2006).

[5] P. Blood and J.W. Orton, The Electrical Characterization of Semiconductors: Majority Carriers and Electron States (Philips Research Laboratories, Redhill, Surrey RH15HA, UK, 1992). 
[6] I.M. Abdelo-Motaleb and R.Y. Korotkov, J. Appl. Phys. 97, 093715-1-6 (2005).

[7] S. Juillaguett, C. Balloud, T. Robert, M. Zelinski, and J. Camassel, in: Abstracts of International Workshop on 3C-SiC Heteroepitaxy, Grenoble, June 2007, p. 35.

[8] H. Nagasawa, K. Yagi, T. Kawahara, N. Hatta, G. Pensl, W.J. Choyke, T. Yamada, K.M. Itoh, and A. Shoner, in: Silicon Carbide: Recent Major Advances, eds. W.J. Choyke, H. Matsunami, and G. Pensl (Springer, Berlin, 2004) pp. 207-228.

[9] J. Singh, Electronic and Optoelectronic Properties of Semiconductor Structures (Cambridge University Press, Cambridge, 2003).

[10] T.T. Mnatsakanov, M.E. Levinshtein, L.I. Pomortseva, and S.N. Yurkov, Semicond. Sci. Technol. 17, 974-977 (2002).

[11] T.T. Mnatsakanov, L.I. Pomortseva, and S.N. Yurkov, Semicond. 35(4), 394-397 (2001).

[12] H. Matsuura, M. Komeda, S. Kagamihara, H. Iwata, R. Ishihara, T. Hatakeyama, T. Watanabe, K. Kojima, T. Shinohe, and K. Arai, J. Appl. Phys. 96, 2708-2715 (2004).

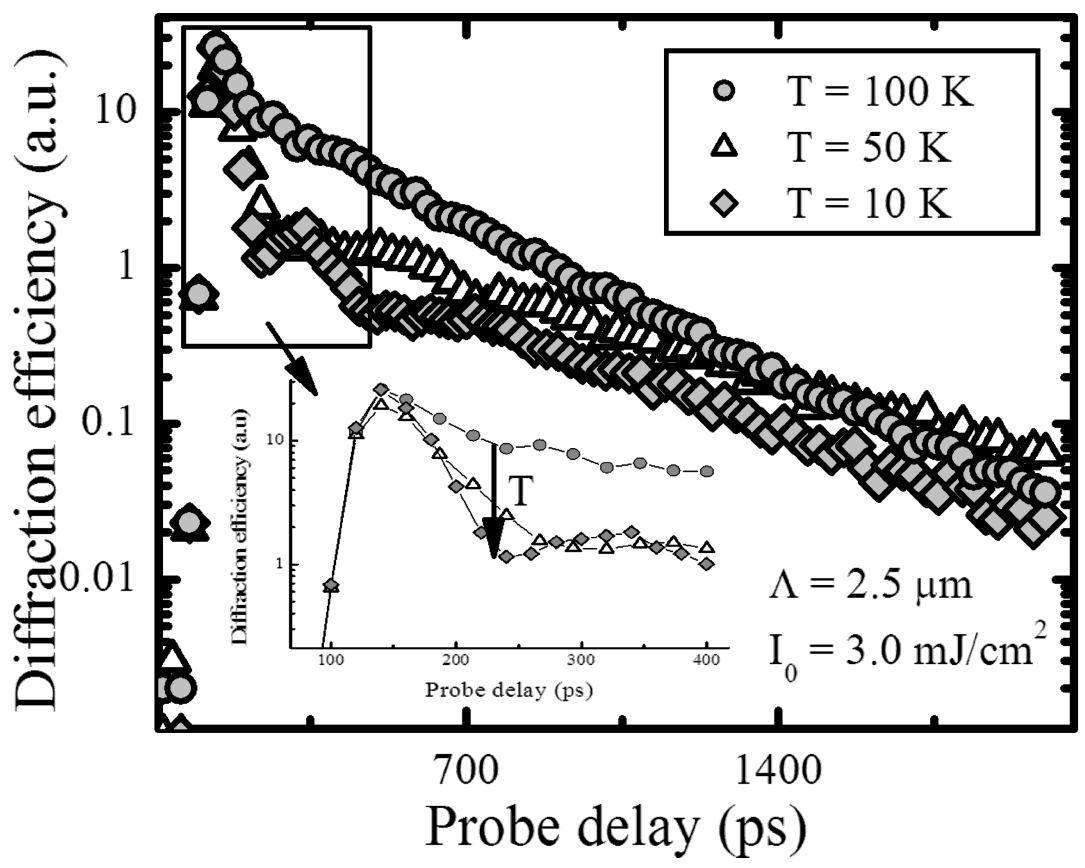

Fig. 5. Kinetics of grating diffraction efficiency measured at different temperatures for the fixed grating period in free standing 3C-SiC. In the inset: grating decay kinetics at first 300 ps after excitation.

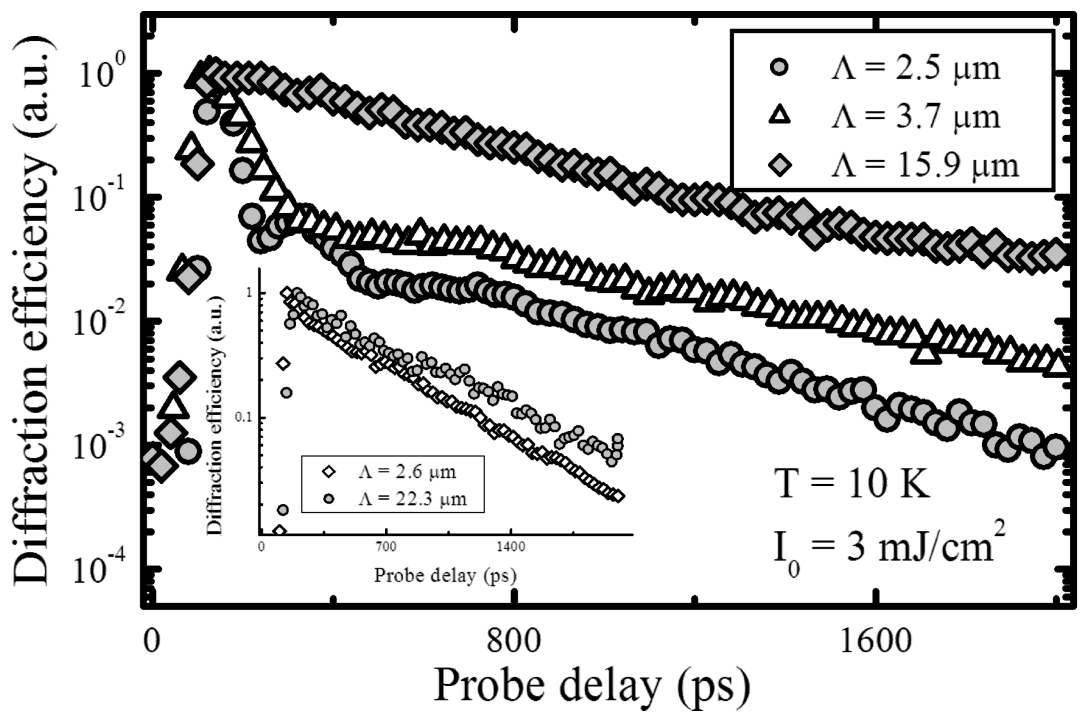

Fig. 6. Kinetics of grating diffraction efficiency measured at different grating periods for the fixed temperature in free standing and DBP free (in the inset) $3 \mathrm{C}-\mathrm{SiC}$ samples. 
[13] W.J. Shatter, H.S. Kong, G.H. Negley, and J.W. Palmour, Inst. Phys. Conf. Ser. 137, 155-158 (1994).

[14] K. Neimontas, T. Malinauskas, R. Aleksiejūnas, R. Yakimova, and K. Jarašiūnas, Lithuanian J. Phys. 46,
199-204 (2006).

[15] J. Vaitkus, K. Jarašiūnas, E. Gaubas, L. Jonikas, R. Pranaitis, and L. Subačius, IEEE J. Quantum Electron. 22, 1298-1306 (1986).

\title{
SiC KRISTALŲ TYRIMAI OPTINIAIS IR ELEKTRINIAIS METODAIS
}

\author{
K. Neimontas, R. Vasiliauskas, A. Mekys, J. Storasta, K. Jarašiūnas
}

Vilniaus universitetas, Vilnius, Lietuva

\section{Santrauka}

Keturbangio maišymo bei Holo efekto metodikomis atlikti temperatūriniai nepusiausvirujų krūvininkų dinamikos matavimai $n$ tipo 4H-SiC ir 3C-SiC epitaksiniuose sluoksniuose bei 3C-SiC kvazitūriniame kristale. Išmatuotos bipolinio krūvininkų judrio (difuzijos koeficiento) priklausomybès $100-300 \mathrm{~K}$ temperatūros intervale. Iš abiem metodikomis išmatuotu priklausomybiu $4 \mathrm{H}-\mathrm{SiC}$ epitaksiniuose sluoksniuose $\left(\mu \sim T^{-3 / 2}\right)$ nustatyta, kad pagrindinis krūvininkų sklaidos mechanizmas yra sklaida fononais visame matuotos temperatūros intervale (100-300 K). Rastos didesnès difuzijos koeficiento vertès cheminiu garų nusodinimo metodu užaugintame $4 \mathrm{H}-\mathrm{SiC}$ epitaksiniame sluoksnyje, lyginant su sublimacijos būdu užaugintu bandiniu. Šis skirtumas paaiškinamas skirtingu defektų tankiu abiejuose bandiniuose. Iš išmatuotų krūvininkų judrio temperatūrinių priklausomybių $3 \mathrm{C}$-SiC bandiniuose padaryta išvada, kad sklaida jonizuotomis priemaišomis riboja judrio vertę, kai $T<100 \mathrm{~K}$, o esant $T>100 \mathrm{~K}$ vyrauja sklaida fononais. Judrio vertės mažèjimas didinant žadinančios šviesos energijos tanki (nepusiausvirụjų krūvininkų tankį) kvazitūriniame kristale aiškinamas priemaišų perelektrinimu esant dideliems krūvininkų tankiams. Didesnès judrio vertès (visuose matuotos temperatūros ir žadinančios šviesos energijos tankio intervaluose) kvazitūriniame 3C-SiC lyginant su epitaksiniu sluoksniu rodo geresnes jo elektrines savybes. Nustatyta, kad esant žemai temperatūrai $(T<100 \mathrm{~K} 4 \mathrm{H}-\mathrm{SiC}$ atveju ir $T<50 \mathrm{~K} 3 \mathrm{C}$-SiC atveju) kristalinès gardelès kaitinimas dèl nespindulinès laisvụjų krūvininkų rekombinacijos ir energijos perviršio, susidarančio žadinant kristalą šviesos kvantu $h \nu>E_{\mathrm{g}}$, sukelia temperatūrinę lūžio rodiklio moduliaciją, kuri turi didelę ịtaką difrakcijos efektyvumo kinetikoms, ir dèl to nebegalima tiesiogiai ivertinti nepusiausvirujų krūvininkų judrio šiuose kristaluose. Reikia pažymėti, kad epitaksiniame 3C-SiC sluoksnyje šis efektas nebuvo stebimas, ir tai rodo mažesni nespindulinès rekombinacijos kanalų kiekị, lyginant su kvazitūriniu 3C-SiC kristalu. 